\title{
Signs of carcinogenicity induced by parathion, malathion, and estrogen in human breast epithelial cells (Review)
}

\author{
GLORIA M. CALAF ${ }^{1,2}$, TAMMY C. BLEAK ${ }^{1}$ and DEBASISH ROY ${ }^{3}$ \\ ${ }^{1}$ Instituto de Alta Investigación, Universidad de Tarapacá, Arica 1000000, Chile; ${ }^{2}$ Center for Radiological Research, \\ Columbia University Medical Center, New York, NY 10032; ${ }^{3}$ Department of Natural Sciences, \\ Hostos Community College of The City University of New York, Bronx, NY 10451, USA
}

Received November 17, 2020; Accepted January 29, 2021

DOI: $10.3892 /$ or.2021.7975

\begin{abstract}
Cancer development is a multistep process that may be induced by a variety of compounds. Environmental substances, such as pesticides, have been associated with different human diseases. Organophosphorus pesticides (OPs) are among the most commonly used insecticides. Despite the fact that organophosphorus has been associated with an increased risk of cancer, particularly hormone-mediated cancer, few prospective studies have examined the use of individual insecticides. Reported results have demonstrated that OPs and estrogen induce a cascade of events indicative of the transformation of human breast epithelial cells. In vitro studies analyzing an immortalized non-tumorigenic human breast epithelial cell line may provide us with an approach to analyzing cell transformation under the effects of OPs in the presence of estrogen. The results suggested hormone-mediated effects of these insecticides on the risk of cancer among women. It can be concluded that, through experimental models, the initiation of cancer can be studied by analyzing the steps that transform normal breast cells to malignant ones through certain substances, such as pesticides and estrogen. Such substances cause genomic instability, and therefore tumor formation in the animal, and signs of carcinogenesis in vitro. Cancer initiation has been associated with an increase in genomic instability, indicated by the inactivation of tumor-suppressor genes and activation of oncogenes in the presence of malathion, parathion, and estrogen. In the present study, a comprehensive summary of the impact of OPs in human and rat breast cancer, specifically their effects on the cell cycle, signaling pathways linked to epidermal growth factor, drug metabolism, and genomic instability in an MCF-10F estrogen receptor-negative breast cell line is provided.
\end{abstract}

Correspondence to: Dr Gloria M. Calaf, Instituto de Alta Investigación, Universidad de Tarapacá, 1520 Calle Antofagasta, Arica 1000000, Chile

E-mail: gmc24@cumc.columbia.edu

Key words: carcinogenesis, breast cell line, parathion, malathion, estrogen

\section{Contents}

1. Introduction

2. Data collection

3. Parathion and malathion increase cell proliferation

4. Parathion and malathion modulate epidermal growth factor receptor and estrogen receptor expression

5. Parathion and malathion induce metabolic alterations

6. Parathion and malathion cause genomic instability

7. Conclusions

\section{Introduction}

Environmental substances appear to be involved in various human diseases, including breast cancer $(1,2)$. Based on epidemiological evidence, several studies have found an association between human cancer and exposure to agricultural pesticides, such as organophosphorus pesticides (OPs) (3-5). Generally, OPs can protect agricultural products for decades and have therefore been widely used, particularly malathion, to control vectors (6). Parathion has also been used as a pesticide in agricultural settings. These pesticides, however, pose a serious threat to multiple organisms, including humans. For instance, certain pesticides have been associated with blood diseases, such as non-Hodgkin's lymphoma (7-9) and leukemia $(10,11)$.

Other pesticides, including organochlorines, creosote, and sulfallate, have been reported to be carcinogenic in in vivo studies (12), whereas dichlorodiphenyltrichloroethane, chlordane, and lindane have been found to act as tumor promoters (13-15). However, individual pesticides have only been evaluated in a limited number of human studies. In addition, certain substances in commercial pesticide formulations may pose a carcinogenic risk to humans $(15,16)$. Thus the International Agency for Research on Cancer (IARC) (17) classified parathion as 'possibly carcinogenic' (Group 2B) and malathion as 'probably carcinogenic' to humans (Group 2A). Furthermore, experimental studies have proposed that malathion or its derivatives could be carcinogenic, indicating that impurities found in commercial malathion, such as malaoxon and isomalathion, induce DNA damage $(18,19)$.

The etiology of breast cancer remains unclear, and humans are exposed not only to pesticides but also to a mixture of 
estrogenic agents (20). Estrogens have been implicated in the etiology of breast cancer by epidemiological and experimental evidence (21-24). Moreover, the importance of hormones in mammary cancer (25), as well as the effect of a variety of compounds on this process $(26,27)$, have been demonstrated. The exposure of human populations to these substances renders it necessary to consider the effect of pesticides and estrogens on human health.

Studies using various human epithelial cell lines have been performed to analyze the cellular and biological processes involved in transforming a normal cell into a cell with a malignant phenotype $(28,29)$. Furthermore, the use of experimental animals and cells in the laboratory has allowed us to determine whether these environmental substances induce breast cancer $(20,21,30-36)$. Table I shows the phenotypic characteristics of cell lines.

The use of the MCF-10F immortalized normal human breast epithelial cell line has enabled the detection of the sensitivity to several substances, such as 7,12-dimethylbenz(a) anthracene (DMBA) and benzo(a)pyrene (BP) (37), and physical factors, such as ionizing radiation (38), and the determination of their carcinogenic properties.

The present study aimed to summarize the in vitro signs of transformation induced by environmental substances, such as malathion and parathion, in the presence of an endogenous substance, such as estrogen, through the use of the MCF-10F human immortalized breast cell line. This type of cell line is an important tool in the experimental study of breast carcinogenesis induction by hormones or transfection with a c-Ha-ras, or its prevention by antioxidants, such as curcumin (39-41). Table I shows the effect of malathion, parathion, and estrogen on anchorage independence and the invasive capabilities of treated cells. The MCF-10F cell line treated with malathion or parathion alone and in combination with estrogen induced anchorage-independent growth and invasion; however, the same cell line treated with estrogen alone and the control were negative under the same conditions. A previous study demonstrated that estrogen exerts its effects when combined with pesticides in this model, providing an approach to studying this process (35). A new approach has emerged for analyzing carcinogens by the IARC and previous studies; carcinogens were classified based on 10 common characteristics associated with carcinogenesis $(17,42,43)$.

\section{Data collection}

In the present review, a search on MEDLINE (through PubMed), Web of Science, and SCOPUS was conducted between January 2020 and June 2020 to identify studies examining the in vitro changes of the normal MCF-10F human breast epithelial cell line under the effect of pesticides in the presence of estrogen. The selection was based on cell transformation assays using the MCF-10F cell line to examine the following: i) Cell proliferation by the trypan blue exclusion method; ii) cell growth in a semisolid medium by anchorage-independent assay; iii) cell invasion by cell invasion assay; iv) oncoprotein by immunocytochemistry coupled with confocal microscopy; v) gene expression in several arrays with cell cycle-related key genes; human drug metabolism in gene array including genes that encode important receptors and several enzymes involved in drug transport and phase I and phase II metabolism; and vi) genomic instability in a human cancer oligo array.

\section{Parathion and malathion increase cell proliferation}

The association between OPs and estrogen was analyzed in relation to mammary carcinogenic capability. Exposure to OPs can be considered an important initiator of breast cancer, as shown by several signs of carcinogenicity detected in vivo and in vitro. The in vivo studies were based on morphological and molecular experiments using Sprague-Dawley rats. Since malathion significantly increased the density of terminal end buds (TEBs), this research allowed us to obtain a model of the initiation of mammary gland cancer. The primary outcome in rats was the increase of mammary cells in TEBs that were then transformed into proliferative ducts by malathion or parathion, eventually resulting in ductal mammary carcinomas morphologically similar to those found in the breast $(30,31,44)$.

When the animal was injected with estrogens, the formed TEBs were transformed into proliferative lobules full of secretions, with a decreased density of alveolar buds, resulting in actively growing tumors $(30,31,44)$; the pathology of these tumors was of the lobular type. Both the ductal and lobular mammary carcinomas were similar to those classified by the World Health Organization. When the animals were exposed to pesticides and estrogen, both types of structures such as ducts and lobules were observed. Mammary gland tumors then metastasized to the bronchi, lungs, and kidneys. The effect of OPs was avoided by atropine demonstrating an association of atropine with the muscarinic receptor. In vivo studies showed signs of carcinogenicity, including cell proliferation leading to tumor formation and genomic instability (32). The mechanisms for mammary carcinogenic potential included acetylcholinesterase inhibition, increased oxidative stress, decreased apoptotic signaling, and endocrine-disrupting capabilities.

Parathion (33) and malathion (20) had been previously found to increase cell proliferation and induce cell transformation affecting protein expression in the MCF-10F cell line $(20,33,34,36,45)$. It was found that malathion alone or in the presence of estrogen, induced anchorage-independent growth, cell invasive capabilities, altered cell cycle regulation, and increased genomic instability in the MCF-10F breast cell line in vitro $(20,36)$. Another study demonstrated that malathion induced changes in gene expression (45). A scheme of exposure to OPs, estrogen, and chemical structures of malathion and parathion is presented in Fig. 1.

When the established model was initially developed, morphological changes were the first observed signs in vitro, which included a changing doubling time, colony agar formation, and invasive capabilities, all indicative of a very aggressive phenotype, as compared to the control cells $(20,21,33,36,38,46-49)$. On the other hand, it was observed that atropine, an antagonist of muscarinic receptors, when combined with any of these pesticides inhibited all aforementioned effects (33).

The same was observed in another cell line, the MCF-7 malignant breast cancer cell line, in which estrogen markedly increased cell proliferation in vitro after 6 days (44). 
Table I. Phenotypic characteristics of cell lines (20).

Treatment

Anchorage independent growth assay

Invasion assay

MCF-10F without treatment

MCF-10F treated with E2 $\left(10^{-8} \mathrm{M}\right)$

MCF- $10 \mathrm{~F}$ treated with $\mathrm{M}(0.5 \mu \mathrm{g} / \mathrm{ml})$

MCF-10F treated with $\mathrm{M}$ and E2

MCF-10F treated with $\mathrm{P}(100 \mathrm{ng} / \mathrm{ml})$

MCF-10F treated with $\mathrm{P}$ and E2

E2, $17 \beta$ estradiol; $\mathrm{M}$, malathion; $\mathrm{P}$, parathion
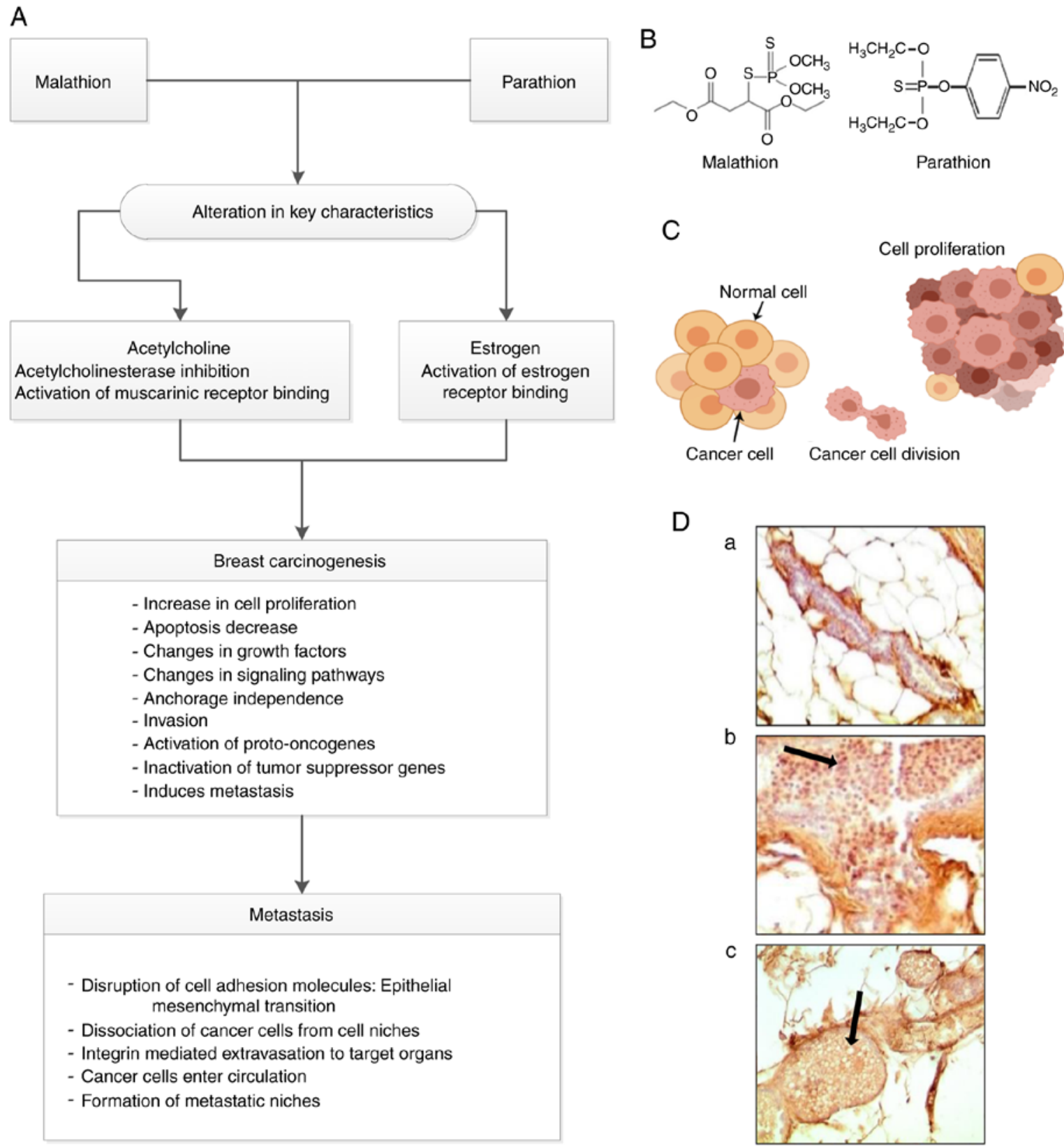

Figure 1. Breast carcinogenesis induced by organophosphorus pesticides (OPs), malathion and parathion. (A) Schematic diagram of key carcinogenicity characteristics. (B) Chemical structures of malathion and parathion. (C) Scheme of cell proliferation. (D) In vivo studies: Representative images of protein expression in cross-sections of tissues derived from female Sprague-Dawley rat mammary glands exposed to malathion and atropine. (D-a) Normal duct, (D-b) ductal carcinoma derived from malathion-treated rats immunostained with Rho-A where cells are observed (arrow), and (D-c) ductal carcinoma derived from atropine-treated rats immunostained with c-Ha-Ras where vacuoles instead of cells are observed (arrow). All images were obtained from our own laboratory for this review. Tissues derived from animals were obtained out of a repository of paraffin blocks performed in a previous study (31). 
Moreover, it was reported that sumithrin, a pyrethroid pesticide used to control pests in agriculture (50), also induced proliferation in vitro at $10^{-7} \mathrm{M}$ and $10^{-5} \mathrm{M}$ doses after 6 days of treatment (51). In addition, in mammalian cells, the pesticide parathion-methyl increased the number of cells and changes in the MCF-7 cell line at low concentrations, exerting toxicity and altering cell-cell interactions in human intestinal cells; it also had other effects on murine fibroblasts, such as increased DNA synthesis (52). These studies demonstrated not only a cell proliferation effect but also other possible physiological effects with a serious impact on humans.

It can be hypothesized that one possible mechanism for breast cancer development is the consequence of excessive estrogenic stimulation that induces cell proliferation of normal breast epithelial tissue (53). More specifically, the malignant phenotype is developed through errors in cell division (DNA copying errors, translocations); furthermore, estrogen is known to control the growth of several carcinomas in experimental animals and humans (53).

Although MCF-10F cells are estrogen receptor (ER)-negative, they were found to be very sensitive to $17 \beta$-estradiol (E2) at $10^{-8} \mathrm{M}$ since cell proliferation increased (1.6 fold) after 10 days of culture (53). The addition of E2 and $10^{-6} \mathrm{M}$ tamoxifen to the MCF-10F cells gave similar results to those of the malignant carcinomas in vitro since it was found that E2 increased cell proliferation, as compared with the control. However, tamoxifen alone and tamoxifen plus E2 inhibited cell proliferation more notably when compared to E2 alone. The association between cell proliferation and proteins involved in cell cycle regulation was also investigated $(54,55)$. When cell cycle control is lost, cells are able to continue dividing (55). When the cell cycle becomes deregulated, it can lead to aberrant cell proliferation, eventually resulting in cancer (56). This observation prompted the analysis of gene expression during the cell cycle as well as its regulation and proliferation.

Differential gene expression was studied using the Oligo GEArray ${ }^{\circledR}$ human cancer microarray (cat. no. OHS-802) in estrogen- and pesticide-treated MCF-10F breast epithelial cells. The results indicated that parathion and estrogen alone, or a combination of the two, induced transcriptional alterations in 22/96 genes from a cDNA array. These alterations involved genes associated with the regulation of the cell cycle, such as cyclins A1, A2, C, D3, G1, G2, and H, cyclin-dependent kinases (CDKs), including $C D K 41$, and minichromosome maintenance protein complex (MCM), a 2-7 hexameric helicase, including MCM2 and MCM3 (20,21). Regarding cyclins, this family of proteins, particularly D-type cyclins, form a complex with CDKs, which affects the cell cycle at the G1 phase $(57,58)$, regulating the cell cycle as a whole (59). Pesticides have been shown to have an affinity for CDKs, with OPs exhibiting a particular affinity for $C D K 2$ and $C D K 4$, which affects cell cycle regulation in mammalian cells and other pesticides, such as carbamates and synthetic pyrethroid; these were also evaluated, and a positive interaction was identified between them and CDKs at low doses (60).

Previous studies have indicated that the cyclin A2 gene was downregulated by all the substances under study and, whereas cyclin $\mathrm{C}$ and cell division cycle $6(C D C 6)$ were upregulated 3 -fold by parathion, as compared with the control. Cyclin D3 gene was upregulated by both estrogen and parathion. Cyclin-dependent kinase $C D K N I A$ was upregulated 3 -fold by parathion alone, and $C D K N 2 C$, which is associated with cell cycle checkpoint and cell cycle arrest, was downregulated by both estrogen and parathion (21).

Furthermore, different treatments of pesticides alone or in combination with estradiol were shown to upregulate the cyclin D1 and $C D K$ genes. Of note, the resulting proteins were involved in the phosphorylation of important effectors associated with different stages of the cell cycle (61-64). A previous study revealed upregulation by the effect of E2 in combination with the pesticide compounds, including the upregulation of cyclin family genes, including keratin 18 (20). These results were in agreement with previous findings (33).

The MCM2 family of proteins was upregulated by both malathion and parathion. The MCM family of proteins is known to be involved in the regulation of DNA replication $(65,66)$. It has been reported that the expression of MCM proteins increases during DNA replication (67). The MCM proteins controlled by E2F transcription factors have been shown to promote MCM expression (68). The protein kinase complexes interact with MCM proteins maintaining the post-replication stage and MCM2/MCM4 serve as substrates for CDC2/cyclin B (69-71). MCM3 cleavage can be prevented by caspase inhibitors, resulting in MCM complex inhibition during apoptosis (72). Furthermore, the MCM4, MCM6, and $M C M 7$ complexes have been found to be involved in DNA helicase activity $(71,73)$. In addition, results indicated that parathion and estrogen upregulated the MCM6 labeling index, as compared with the control value (21). Other studies have reported this index to be correlated with cell proliferation and malignant behavior in chondrosarcomas (74).

p53 is another gene involved in the regulation of the cell cycle, serving as a checkpoint for the $G_{1}-S$ phase (75). At the same time, the $M D M 2$ gene regulates $p 53$ and is associated with tumor growth and metastasis (76). It was observed in previous studies that the combination of parathion and estrogen upregulated MDM2 (21) and downregulated p53 (77), thus increasing tumorigenic capabilities (21). Similarly, a study analyzed peripheral lymphocyte DNA obtained from 180 workers with long-term exposure to OPs. That study reported that omethoate, an OP compound, affected the expression of $p 53$, which in turn had an impact on the length of the telomere, suggesting a clear influence of pesticides over the cell cycle and tumor formation $(75,78)$.

Dishevelled $(D V L)$ is a gene that regulates the migration and proliferation of endothelial cells present in blood vessels $(79,80)$. Malathion and the combination of parathion and estrogen upregulated the DVLI gene and increased the protein expression in cells treated with parathion, alone and combined with estrogen, as compared with the controls (20). The mammalian homologs of the Drosophila DVL together with DVL proteins are important molecules in the Wnt signaling pathway (80-82). DVL-2 protein expression was found to be increased by estrogen, malathion, and parathion, regulating the proliferation of the MCF-10F cell line, as compared with the control (20).

Other studies have also reported that genes associated with cell cycle progression, DNA replication, and checkpoint enzymes were affected by malathion $(45,83,84)$. 
Cyclin-dependent kinases regulatory subunit 1 is also fundamental in cell cycle progression (85), and associated with genes that particularly affect the $\mathrm{G}_{2}$ phase; $\mathrm{G}_{2} / \mathrm{M}$ transition was found to be downregulated in estrogen and parathion treatments (21). These results indicated that pesticides affected the regulation of the cell cycle with possible effects on cancer initiation.

E2 at $10^{-8} \mathrm{M}$ significantly increased cell proliferation; however, as shown in Table I, E2 did not induce anchorage-independent growth, anchorage independence, or invasiveness in Matrigel ${ }^{\circledR}$. Other researchers (86) reported the induction of complete transformation of MCF-10F cells by E2, confirming its carcinogenicity; however, E2-treated-MCF-10F cells were trypsinized and seeded in the upper Matrigel-coated invasion chamber, followed by post-seeding of cells that had crossed the Matrigel membrane, giving origin to several MCF-10F cell lines. E2 induced complete transformation of the human breast epithelial MCF-10F cells in vitro, confirming its carcinogenicity and supporting the concept that this hormone could act as an initiator of breast cancer in women.

\section{Parathion and malathion modulate epidermal growth factor receptor and estrogen receptor expression}

Previous research has indicated that cell growth is affected by the epidermal growth factor (EGF) through its interaction with the EGF receptor (EGFR) (33); since high levels have been found in the surface of different types of cancer cells $(87,88)$ and its association with cancer has been confirmed over the years. The results of a previous study indicated that EGFR protein expression was increased in cells treated with the pesticide alone or in combination with the hormone (21). These results are important, considering that growth factors and their receptors are proteins associated with cell growth $(21,89)$. According to previous results, the parathion-treated MCF-10F cell line induced a higher EGFR/ERBBI protein expression, as compared with control and parathion plus atropine-treated cell lines (21). EGFR is a receptor tyrosine kinase associated with cancer, the overexpression of which is correlated with poor prognosis, solid tumor growth, cancer metastasis, and lower survival rate $(90,91)$. Such results have indicated that pesticides such as parathion induce EGFR expression.

It has been reported that estradiol increases the risk of breast cancer in women after long-term exposure since estrogens increase cell proliferation by activating ER-mediated transcription; however, this interaction has been shown to induce genomic instability, chromosomal aberrations, and an increase in errors during DNA replication $(25,26,92,93)$.

Since the MCF-10F model lacks ER expression, E2 appears to act through ER-independent mechanisms. The ERs are ligand-inducible transcription factors that belong to the superfamily of nuclear steroid hormone receptors $(94,95)$. The transmission of estrogen signaling includes the activation of ERs and signal transduction, which can be mediated by genomic and non-genomic signaling pathways. Such classification is based on the outcome of cellular events, including the modulation of gene expression or activation of signaling cascades. The classic genomic pathway is the best-characterized ERa signaling pathway, which is initiated by the ligand binding to its receptor. The binding induces a conformational change and dissociation of their chaperones/nuclear matrix-associated binding proteins (96), forming the E-ER complexes that translocate to the nucleus and bind to specific DNA sequences; these are called estrogen response elements (EREs) and are located in or near the promoters of target genes (97). An ERE-independent signaling pathway has been reported, where E2-ER complexes can mediate gene expression through functional interactions with transcription factors on the DNA $(98,99)$. ERs may interact with many other proteins, including adaptor proteins, G-proteins, GFRs (EGFR, IGFR1, and HER2), cytoplasmic kinases [mitogen-activated protein kinases (MAPKs), PI3K and AKT], and signaling enzymes, which can eventually lead to indirect changes in gene expression (100).

On the other hand, the influence of ER $\alpha$-signaling pathways on epithelial-to-mesenchymal transition-related transcriptional factors, which are fundamental in the development of breast cancer, has been reported $(34,35,101,102)$.

\section{Parathion and malathion induce metabolic alterations}

It has been reported that pesticides affect the human population, due to their long-term exposure and intensity, and that they alter the detoxification rate by changing the expression of enzymes associated with the transport and metabolism of drugs (103). Briefly, the by-products of drug metabolism are substances that may be pharmacologically active, inactive, or toxic (104). This process is divided into two phases, phase I and phase II; the former is mainly associated with a sophisticated enzymatic complex, known as cytochrome P450 (CYP), whereas the latter is associated with the addition of polar moieties to the substrate, to be eliminated by organisms (105).

Previously, genes involved in human drug metabolism have been analyzed by cDNA microarrays; CYPs, metallothioneins, and p-glycoproteins were further studied (34). CYPs are an enzymatic complex that belongs to the family of monooxygenases, which are involved in the metabolism of endogenous and xenobiotic compounds (106).

According to cDNA microarray, parathion was found to result in $C Y P$ upregulation, whereas estrogen, alone or combined with parathion, induced the downregulation of $C Y P 2 F 1$ and $C Y P 4 F 3$; however, there was no change in the $C Y P 3 A 7$ gene expression following exposure to either substance (34).

Results have shown that catechol formation is a major risk factor for breast cancer (107); since it gives rise to reactive quinones causing DNA damage and redox cycling, which in turn lead to the generation of reactive oxygen species (ROS), which can cause oxidative damage (108).

Other important mechanisms involved in carcinogenic effects, besides the stimulation of cellular proliferation through their receptor-mediated hormonal activity, are the direct genotoxic effects exerted by increasing mutation rates through CYP-mediated metabolic activation. A previous study (86) demonstrated that estrogens are carcinogenic in the human breast by testing the natural E2 or its metabolites, 2-hydroxy, 4-hydroxy and 16-a-hydroxy-estradiol [2-OH-E(2), 4-OH-E(2) and $16-\alpha-\mathrm{OH} \mathrm{E}(2)$, respectively] in an experimental system, and neoplastic transformation of MCF-10F cells was observed, to a degree at least similar to that induced by the BP. 
On the other hand, estradiol metabolism may result in quinone derivatives, which directly replace base pairs from DNA through depurination, and can also alter the DNA repairing process (109-111). It has been reported that estrogens are potent mammary tumor promoters influencing post-initiation events through epigenetic mechanisms. The upregulation of the C16 $\alpha$-hydroxylation pathway during E2 biotransformation was associated with mammary cell transformation. The action of E2 metabolites on tumorigenic transformation was studied in a mammary epithelial cell line derived from the C57BL mouse strain, where estrogen or its metabolites were found to function as initiators of mammary cell transformation demonstrated by increased cell proliferation, anchorage-independent growth, and alteration of metabolism (112).

Metallothioneins are proteins with a low molecular weight that are rich in cysteine domains. These proteins play an important role in metal homeostasis, particularly the detoxification of heavy metals $(113,114)$. Their dysregulated expression has been observed in invasive ductal breast carcinoma, and they have been proposed for use as a prognostic biomarker (115). Metallothionein 2A expression has been found to be associated with cell proliferation in breast cancer $(113,116)$. Furthermore, genes associated with metallothioneins have been shown to be altered by pesticides and estrogen; the only functional gene upregulated by parathion alone was metallothionein IX, with estrogen alone and estrogen plus parathion resulting in its downregulation (34).

In this context, epidemiological studies have found an association between metabolic enzymes and the age of onset for sporadic colorectal adenocarcinoma $(117,118)$. Then, variant alleles of phase II, such as GST, uridine 5'-diphospho-glucoronosyltransferase (UDP), and glucuronosyltransferase (UGT) can be used as molecular biomarkers of cancer risk (119). For example, $\operatorname{GSTM}(\mu) 1$ was found to be associated with an increased risk of colorectal, lung, and bladder cancer, and $\operatorname{GSTP}(\pi) 1$ with prostate cancer (120-123). Furthermore, these enzymes catalyze a large variety of drugs and endogenous compounds, such as molecules with sulfo groups in the case of sulfotransferases $(124,125)$, and are in charge of the biosynthesis of polysaccharides, oligosaccharides, and conjugates, in the case of glucosyltransferases $(126,127)$. Previous studies have indicated that the combination of parathion and estrogen induced the downregulation of all methyltransferase genes, such as TPMT; notably, the CHST5, CHST6, and CHST7 (sulfotransferase) genes were upregulated by parathion and downregulated by estrogen, alone or combined with parathion (34).

The carbohydrate sulfotransferases play a role in oxidative stress and the estradiol signaling pathways in carcinogenesis (128); and have been investigated in breast cancer and glioma patients $(119,129)$. On the other hand, several glycosyltransferases (GSTS) have also been identified; the GSTP1, GSTT2, and microsomal glutathione s-transferase 1 (MGST1) genes were overexpressed by parathion and downregulated by estrogen, when compared to the control, whereas the combination of estrogen and parathion downregulated MGST1, with no change observed in the GSTP1 and GSTT2 genes (34).

As previously reported, UDP-UGT is another enzyme associated with detoxification (130), which was found to be increased by parathion (UGT1AI and UGT2B genes) and decreased by estrogen; however, there was no difference in these genes when the substances were used together (34). Clinical studies have shown an increase in the UGT1Al and $U G T 2 B$ gene expression in ovarian cancer (119); therefore, it can be a reliable molecular biomarker for the risk of cancer. The carcinogenic activity of 4-hydroxyestradiol was analyzed in a hamster kidney tumor model of DNA damage by steroidal estrogens through catechol estrogen metabolites (24,131-133). It is important to note that the 2-hydroxylation of steroidal estrogens is the major metabolic oxidation of estrogenic hormones in most mammalian species $(134,135)$.

Moreover, there are other enzymes with potential carcinogenic activity in the metabolism of endogenous and exogenous compounds $(136,137)$; for example, the enzymes comprising the aldo-keto reductase (AKR) family involved in redox transformation, with substrates such as glucose and steroids, as well as environmental pollutants, among others (138). AKR1C1 and AKR1C2 were also upregulated by another non-organophosphorus pesticide (45). In combination, these examples indicated an impairment of homeostasis by certain substances, ultimately leading to carcinogenesis. Another example is the estrogen-responsive B box protein (139), also upregulated by malathion (137). This protein belongs to the tripartite motif protein family, and its upregulation has been associated with histone acetylation and the transcription of CYP26A1, which is important in retinoid-resistant cancer cells (139).

In this context, particularly in cell metabolism and metabolic pathways, certain studies reported glucose homeostasis impairment (137) and metabolic disorders, with certain metabolic changes still present for a long time even after discontinuing long-term exposure to malathion (140), which was due to OPs. These disturbances may have occurred through physiological stress, oxidative stress, and other mechanisms (141). These results were confirmed by in vivo studies; for example, malathion induced insulin resistance biomarkers and reduced insulin sensitivity (140). Other studies reported that, in general, OPs increased blood glucose (142-144) and induced glycogen phosphorylase and phosphoenolpyruvate carboxykinase activity following malathion treatment in rats (145). Of note, glucose and lipid metabolism were affected in rats under the influence of malathion $(146,147)$.

Similarly, neonatal parathion exposure in rats was found to alter lipid metabolism and induce an inflammatory response in adipose tissue, parathion alone decreased adiponectin levels and increased tumor necrosis factor- $\alpha$ (TNF- $\alpha$ ) (148). Adiponectin is a monomeric protein secreted in the circulation with the main purpose of inducing fatty acid oxidation and inhibiting glucose synthesis in the liver. It has also been recognized as an anti-inflammatory agent (149), whereas TNF- $\alpha$ is a cytokine associated with immune homeostasis, inflammation, apoptosis, angiogenesis, and cell migration $(150,151)$.

These in vivo studies supported the in vitro results and demonstrated that exposure to OPs induces a chronic adipose inflammatory response, leading to the emergence of other diseases, such as diabetes, obesity, and cardiovascular diseases (148).

\section{Parathion and malathion cause genomic instability}

Genomic instability is known to be induced by uncontrolled cell proliferation, with pesticides and estrogen found to 
increase the risk of genetic damage (152), involving changes in the expression of oncogenes and the loss or inactivation of tumor-suppressor genes $(153,154)$; this leads to the accumulation of abnormalities in cells. It was demonstrated by human cancer microarray analysis that endogenous and exogenous agents, including estrogens and OPs, affected 408 genes, 17 of which were involved in human cancer regulation. Among those genes that were altered are those associated with cell cycle progression, cell differentiation, and signal transduction pathways (20). To determine specific genetic changes and their biological consequences is crucial for understanding breast carcinogenesis.

Studies have indicated that mutations in the Ras oncogene observed in cancer cells correspond to the amino acid substitutions at positions 12,13 , and 61 , and it is important to consider that the oncogenic Ras proteins act downstream of effector pathways to induce the deregulation of cell proliferation and abnormal functional properties of cells (155). The results of previous studies have indicated that allelic imbalance at different chromosomal levels involved the overexpression of the $H$-ras oncogene; with the marker mapped for chromosome 11p14.1 showing microsatellite instability (MSI) in malathionand estrogen-treated cells $(156,157)$. A different study showed that malathion or parathion, alone and in combination with estrogen, upregulated H-ras (20). Those findings indicated a loss of heterozygosity $(\mathrm{LOH})$ in parathion and estrogen-treated cells, $\mathrm{LOH}$ in codon 12 in either malathion- or estrogen-treated cells, and MSI in codon 61 of malathion- and estrogen-treated cells (36). Furthermore, it was shown that chemical carcinogens induced mutations in codons 12 and 61 of H-ras (158). Another study provided an example of the genomic instability of the Ras gene in MCF-10F cells under the influence of the two pesticides and the presence of estrogen (20). The use of microsatellite markers can be useful to determine the degrees of allelic imbalance, LOH or MSI (159-161). The specific genomic imbalances in microsatellite regions of specific genes appear to be important in determining the risk of cancer since tumor pathogenesis is associated with specific imbalances and disease prognosis $(162,163)$, and they may serve as specific therapeutic targets. Genomic instability was observed in parathion-, malathion- and estrogen-treated MCF-10F cells in the form of $\mathrm{LOH}$ and MSI (36). The malignant phenotype was characterized by an increase in $H$-ras oncogene expression. On the other hand, microsatellite markers helped determine that the malathion- and estrogen-treated cells exhibited MSI with a marker for $H$-ras mapped in chromosome 11p14.1, and LOH in the presence of malathion or estrogen alone (36). Other studies have reported overexpression of the c-Ha-ras p21 protein in human breast cancer (164-166), indicating that the expression of this protein may serve as a marker of breast cancer progression.

The Trio domains exhibit Rac and Rho activity (167). Rho, another member of the RAS superfamily (168), is present in several cell types and is involved in cell polarity and motility $(169,170)$. Parathion and estrogen, alone and in combination, increased Rho-A protein expression, as compared with the control (21). Kleer et al (170) reported a higher Rho-A protein expression in all breast tumor biopsies, as compared with normal tissues, which was correlated with histological grade; this suggests a role of this protein in tumor progression and indicates that it may serve as a prognostic marker in the clinical setting (21). Rac, a GTP-binding protein of the Ras superfamily, controls several processes, including cell proliferation, cell polarity, and cytoskeletal arrangement (171). Rac was found to be overexpressed in parathion-treated cells; Rac 3 was particularly overexpressed in cells treated with parathion combined with estrogen. In addition, an increase in Trio protein expression was observed in cells treated with parathion, alone and combined with estrogen, when compared to the controls (33). The Trio is a multi-domain protein with two $D V L$-homology/pleckstrin domains $(167,172)$. The c-Kit protein has also been found to be overexpressed in breast cancer $(88,173)$. A previous study demonstrated an increase of c-Kit protein expression in cells treated with parathion, alone and in combination with either atropine or estrogen when compared to their controls (33).

It is known that the activation of tumor-promoting signaling, such as RAS/MAPK signaling, may promote cancer cell proliferation and invasion (174). OPs altered the c-Ha-Ras oncogene and Rho-A, among others, and estrogen affected ER in the MCF-10F cell line $(20,21)$. Based on these findings, it is, therefore, possible to hypothesize a cross-talk between pesticides and estrogen, with the combination of the two inducing morphological and molecular changes indicative of cell transformation, which would be completely different in the absence of estrogen. Therefore, parathion and malathion combined with estrogen have been found to be involved in breast cell carcinogenesis.

Growth factor regulators, such as fibroblast growth factors (FGFs) and their receptors (FGFRs), regulate different cellular processes, including angiogenesis, metastasis, and tumor progression; the deregulation of these factors affects signaling pathways involved in breast cancer (175-178). Acidic $F G F$ $(F G F-1)$, a member of the fibroblast growth factor superfamily, has important functions in DNA synthesis, cell division, and differentiation (179), and it is also critical for the development of different types of cancer (180-182). FGF-2 and its ligand, $F G F R 2$, along with $F G F-1$, one of the main ligands for FGFR1, have been associated with tumor progression, regulation of tumor angiogenesis, and metastasis (183); this is due to their presence in the tumor microenvironment, which enables them to mediate the effects of several different pathways, such as MAPL and PI3K $(177,184)$.

Insulin-like are growth factor-binding proteins (IGFBPs), among which IGFBP3 and IGFBP5 are important for the regulation of IGF signaling (185-188). Exposure to either parathion or malathion upregulated both IGFBP3 and IGFBP5 gene expression (20). Regarding the interaction of these compounds with breast cell receptors and their association with an endocrine-disrupting connotation, a review reported that malathion induced ER activity and served as a weak ER agonist in the MVLN human breast carcinoma cell line (189).

The function of the cadherin-catenin system in cell adhesion and intracellular signaling appears to be the result of different mechanisms $(190,191)$. Thus, the E-cadherin-catenin complex is the target of numerous growth factors and hormone-dependent signaling pathways that regulate its function and expression (191). In general, $\beta$-catenin has been associated with breast cancer progression due to its invasive capabilities (46,192-194), which make it a very sensitive prognostic marker for invasive breast cancer (190,192-194). 


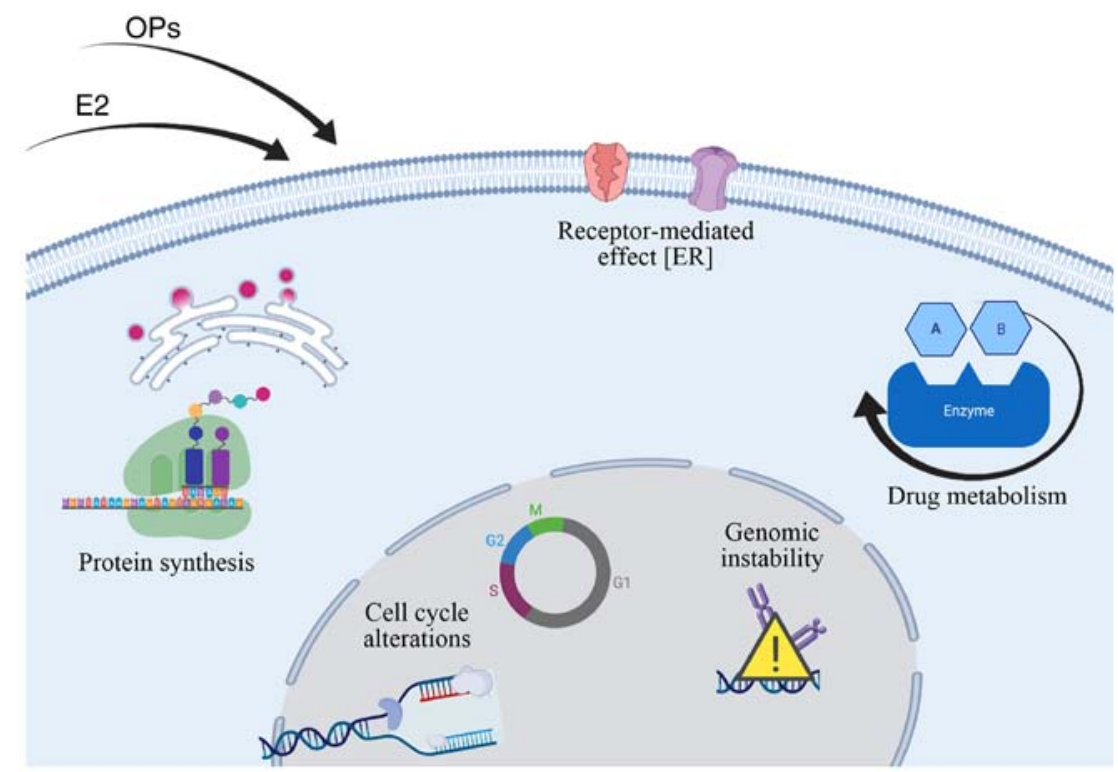

Figure 2. Effect of OPs and estrogen on breast epithelial cells. Parathion, malathion, and estrogen induced alterations on protein synthesis, receptor-mediated response, drug metabolism, and other modifications at the nuclear level, such as cell cycle alterations and genomic instability. OPs, organophosphorus pesticides; E2, estrogen.

Other OPs have also been evaluated in relation to cell adhesion. Specific genes significantly altered by OPs were detected in Caenorhabditis elegans; among them, genes associated with cell adhesion were affected, including C3C12.5, mua-6 (ifa-2), and zig-7 (195). Other studies on these types of organisms have been found to be a good model for investigating the effects of other substances, due to their similarities with mammals (196-199). The same study also investigated genes that were associated with metabolism, including CYTP450 and UDP-glucosyltransferases (195).

Similarly, MCF-10F cells treated with parathion or malathion, alone or combined with estrogen, induced changes in cell adhesion molecules such as CD146 (35), a surface protein also known as melanoma cell adhesion molecule (200) that is involved in cell adhesion and other processes, including cell proliferation, migration and progression, and particularly angiogenesis and vascular permeability (201-204). The aforementioned treatments also upregulated keratin 18 expression; another component of epithelial cells that protects them from external forces, serves as a biomarker in epithelial cancers and plays other roles in drug response and tumorigenesis (205-215).

Heat shock proteins (HSPs) are a group of highly conserved, abundantly expressed proteins with diverse functions (216), including the assembly and sequestering of multi-protein complexes, transportation of polypeptide chains across cellular membranes, regulation of protein folding (217-221), and certain functions that protect against stress-induced injury (137). HSPs are known as molecular chaperones and are organized into six general families according to their molecular weight and activity: HSP20, HSP40, HSP60, HSP70, HSP90, and HSP100 (222). Typically, they are proteins constitutively expressed in the cytoplasm that co-localize to the nucleus under stress induced by physical and chemical insult. Among them, HSP90 and HSP27 are associated with poor prognosis and likely play an important role in drug-resistant breast cancer (223), as well as serve as a biomarker due to toxicant exposure (224). A previous study showed that the gene expression of HSP27 and HSP90 was upregulated by malathion or parathion, alone or combined with estrogen (20). The overexpression of HSP27 and HSP90 may suggest an association between them and breast cancer. Other HSPs such as HSP70 were also upregulated by OPs, an upregulation positively correlated with ROS generation and apoptotic cell death, suggesting an association between pesticides and adverse conditions promoting cell and tissue injury (217-221).

It is well known that the cell cycle involves many steps that can be positively or negatively regulated by several factors. The p53 protein is a negative regulator, and its inactivation by mutation, or its interactions with oncogene products of DNA tumors, may lead to cancer (225-228). Furthermore, it has been reported that malathion or parathion, alone or combined with estrogen, led to the upregulation of the gene expression of inducible protein TP53. TP53 was upregulated and the mutant p53 gene expression was higher in parathion and estrogen-treated cells, as compared with the controls, while the TP53 gene in Li-Fraumeni syndrome was upregulated by malathion or estrogen treatment (20). As previously mentioned, molecular disorders, such as MSI and LOH, are associated with genomic stability (229); furthermore, the TP53 gene is located on chromosome $17 \mathrm{p} 13$. It was reported that malathion mixed with estrogen induced MSI at loci 17p13.1 (36). This indicated that the loss of p53 function can cause the genetic instability of these transformed cells. Thus, mutant p53 can act as a dominant oncogene (86). These findings suggested that OPs and estrogen induced the malignant transformation of the MCF-10F cell line, as shown by the phenotypic characteristics and genomic instability indicated by LOH and MSI, which are considered important events in the process of carcinogenesis.

Studies have shown that breast cancer is associated with alterations in the $p 53$ gene in humans (230), and that mutant p53 expression increases as breast cancer progresses from early in situ to advanced metastatic lesions, with p53 gene mutations observed in $\sim 20-50 \%$ of human cancers $(226,228)$. On the other 
hand, a small number of mutations in $p 53$ have been found in ductal breast carcinomas $(231,232)$. The $p 53$ gene was reported to be altered in $17 \mathrm{p} 13.1$ during cell transformation and genotoxic stress $(157,233)$.p53 was found to be overexpressed in the MCF-10F cell line when it was exposed to several carcinogens, including DMBA and $\mathrm{BP}$, and $\alpha$ particle (high LET) radiation in the presence of estrogen, inducing an allelic imbalance at the respective chromosomal loci $(33,46,47)$.

In addition, the extent of DNA damage can be quantitatively measured by tail moment (TM), which has been widely used in a genotoxic study (234). An increased TM was observed in human peripheral blood lymphocytes following malathion and parathion exposure, as determined by a comet assay, this study also suggested a role of oxidative stress induced by pesticides in the cytotoxic and genotoxic process (235). Similar results were observed in other cell types, such as the HepG2 human liver carcinoma cells, in which malathion also increased the extent of DNA damage $(236,237)$.

Summary of important findings. A cellular model was presented herein, which was based on the use of the MCF-10F cell line, a human tissue-derived, immortalized, a non-tumorigenic cell line that enables a valuable experimental approach that minimizes extrapolation, thereby uniquely facilitating the clinical translation of the data. The cellular and molecular endpoints altered throughout these studies in response to treatment with estrogen, malathion, and parathion represent relevant endpoints for tumorigenic transformation. Of note, this is a unique experimental approach that identifies mechanistic signs that link OPs with human carcinogenesis.

A non-malignant cell line, MCF-10F, was used to construct another model, which showed several signs of carcinogenicity due to malathion and parathion exposure, which increased cell proliferation and induced cell transformation by affecting protein expression, promoted anchorage independence, invasive capabilities, modulation of receptor expression, metabolic alterations and genomic instability, among others. The mechanisms underlying the mammary carcinogenic potential involved acetylcholinesterase inhibition and increased oxidative stress. A simplified scheme of the molecular changes induced by the effects of OPs and estrogen is shown in Fig. 2.

\section{Conclusions}

Exposure to chemical compounds, such as pesticides, and endogenous substances, such as estrogens, exert a significant effect on normal breast cell processes at different levels. Compounds of natural origin, such as hormones, are closely associated with hormone-dependent types of cancer, including breast cancer. The present study provides a comprehensive summary of the impact of parathion, malathion, and estrogen on breast carcinogenesis and, specifically, their effects on cell cycle, signaling pathways linked to EGF and IGF receptors, drug metabolism, and genomic instability in the ER-negative breast cell line MCF-10F.

Cancer initiation and progression have been correlated with an increase in genomic instability identified by the inactivation of tumor-suppressor genes, and the activation of oncogenes in the presence of malathion, parathion, and estrogen. Moreover, advances in science and medicine have helped further identify and elucidate the functions of useful tumor markers or signaling molecules, further enhancing our understanding of genetic changes that are relevant to tumor initiation. Therefore, the signs of carcinogenicity have been proven to be very useful for analyzing the main factors involved in breast cancer initiation and may be used for determining the origin of other types of cancer and the main contributing factors.

\section{Acknowledgements}

The authors would like to thank Mr. Leodán A. Crispin (Instituto de Alta Investigación, Universidad de Tarapacá) for providing technical support.

\section{Funding}

The present study was funded by the Convenio de Desempeño UTA1117 (to GMC) grant from Universidad de Tarapacá and Fondo Nacional de Ciencias grant. no. 1200656 (to GMC).

\section{Availability of data and materials}

Not applicable.

\section{Authors' contributions}

GMC prepared the original draft. GMC, TCB, and DR reviewed and edited the manuscript. All authors have read and approved the final version of the manuscript.

\section{Ethics approval and consent to participate}

Not applicable.

\section{Patient consent for publication}

Not applicable.

\section{Competing interests}

The authors declare that they have no competing interests.

\section{References}

1. Guyton KZ, Loomis D, Grosse Y, El Ghissassi F, Benbrahim-Tallaa L, Guha N, Scoccianti C, Mattock H and Straif K; International Agency for Research on Cancer Monograph Working Group, IARC, Lyon, France: Carcinogenicity of tetrachlorvinphos, parathion, malathion, diazinon, and glyphosate. Lancet Oncol 16: 490-491, 2015.

2. Rich JD, Gabriel SM and Schultz-Norton JR: In vitro effects of herbicides and insecticides on human breast cells. ISRN Toxicol 2012: 232461, 2012.

3. Lerro CC, Koutros S, Andreotti G, Friesen MC, Alavanja MC, Blair A, Hoppin JA, Sandler DP, Lubin JH, Ma X, et al: Organophosphate insecticide use and cancer incidence among spouses of pesticide applicators in the Agricultural Health Study. Occup Environ Med 72: 736-744, 2015.

4. Alavanja MC, Ross MK and Bonner MR: Increased cancer burden among pesticide applicators and others due to pesticide exposure. CA Cancer J Clin 63: 120-142, 2013.

5. Sabarwal A, Kumar K and Singh RP: Hazardous effects of chemical pesticides on human health-Cancer and other associated disorders. Environ Toxicol Pharmacol 63: 103-114, 2018.

6. Popp J, Peto K and Nagy J: Pesticide productivity and food security. A review. Agron Sustain Dev 33: 243-255, 2013. 
7. Cantor KP, Blair A, Everett G, Gibson R, Burmeister LF, Brown LM, Schuman L and Dick FR: Pesticides and other agricultural risk factors for non-Hodgkin's lymphoma among men in Iowa and Minnesota. Cancer Res 52: 2447-2455, 1992.

8. McDuffie HH, Pahwa P, McLaughlin JR, Spinelli JJ, Fincham S, Dosman JA, Robson D, Skinnider LF and Choi NW: Non-Hodgkin's lymphoma and specific pesticide exposures in men: Cross-Canada study of pesticides and health. Cancer Epidemiol Biomarkers Prev 10: 1155-1163, 2001.

9. Hu L, Luo D, Zhou T, Tao Y, Feng J and Mei S: The association between non-Hodgkin lymphoma and organophosphate pesticides exposure: A meta-analysis. Environ Pollut 231: 319-328, 2017.

10. Brown LM, Blair A, Gibson R, Everett GD, Cantor KP, Schuman LM, Burmeister LF, Van Lier SF and Dick F: Pesticide exposures and other agricultural risk factors for leukemia among men in Iowa and Minnesota. Cancer Res 50: 6585-6591, 1990.

11. Soldin OP, Nsouli-Maktabi H, Genkinger JM, Loffredo CA Ortega-Garcia JA, Colantino D, Barr DB, Luban NL, Shad AT and Nelson D: Pediatric acute lymphoblastic leukemia and exposure to pesticides. Ther Drug Monit 31: 495-501, 2009.

12. Costa LG: Organophosphorus compounds at 80: Some old and new issues. Toxicol Sci 162: 24-35, 2018.

13. Shen K and Novak RF: DDT stimulates c-erbB2, c-met, and STATS tyrosine phosphorylation, Grb2-Sos association, MAPK phosphorylation, and proliferation of human breast epithelial cells. Biochem Biophys Res Commun 231: 17-21, 1997.

14. Bharathi SP, Raj HM, Jain S, Banerjee BD, Ahmed T and Arora VK: Role of pesticides in the induction of tumor angiogenesis. Anticancer Res 33: 231-240, 2013.

15. Dich J, Zahm SH, Hanberg A and Adami HO: Pesticides and cancer. Cancer Causes Control 8: 420-443, 1997.

16. Bassil KL, Vakil C, Sanborn M, Cole DC, Kaur JS and Kerr KJ: Cancer health effects of pesticides: Systematic review. Can Fam Physician 53: 1704-1711, 2007.

17. International Agency for Research on Cancer (IARC) Some organophosphate insecticides and herbicides IARC Working Group on the Evaluation of Carcinogenic Risks to Humans. Monograph 112. IARC, Lyon, 2017. https://monographs.iarc.fr/iarc-monographs-on-the-evaluation-ofcarcinogenic-risks-to-humans-4/Accessed July 2017

18. Blasiak J, Jaloszynski P, Trzeciak A and Szyfter K: In vitro studies on the genotoxicity of the organophosphorus insecticide malathion and its two analogues. Mutat Res 445: 275-283, 1999.

19. Berkman CE, Quinn DA and Thompson CM: Interaction of acetylcholinesterase with the enantiomers of malaoxon and isomalathion. Chem Res Toxicol 6: 724-730, 1993

20. Calaf GM and Roy D: Cancer genes induced by malathion and parathion in the presence of estrogen in breast cells. Int J Mol Med 21: 261-268,2008.

21. Calaf GM and Roy D: Gene and protein expressions induced by 17beta-estradiol and parathion in cultured breast epithelial cells. Mol Med 13: 255-265, 2007.

22. International Agency forResearchonCancer(IARC):SexHormones (II). IARC Monographs on the Evaluation of the Carcinogenic Risk of Chemicals to Humans. Monograph 21. IARC, Lyon, 1979. https://publications.iarc.fr/Book-And-Report-Series/IarcMonographs-On-The-Identification-Of-Carcinogenic-HazardsTo-Humans/Sex-Hormones-II-1979. Accessed January 2020.

23. International Agency for Research on Cancer (IARC): Overall Evaluations of Carcinogenicity: An Updating of IARC Monographs Volumes 1-42. IARC Monographs on the Evaluation of Carcinogenic Risks to Humans Supplement 7. IARC, Lyon, 1987. https://publications.iarc.fr/Book-And-ReportSeries/Iarc-Monographs-Supplements/Overall-Evaluations-OfCarcinogenicity-An-Updating-Of-IARC-Monographs-Volumes$1 \%$ E2\%80\%9342-1987. Accessed January 2020.

24. International Agency for Research on Cancer (IARC): Hormonal Contraception and Post-menopausal Hormonal Therapy. IARC Monographs on the Evaluation of Carcinogenic Risks to Human. Monograph 72. IARC, Lyon, 1999. https:// publications.iarc.fr/Book-And-Report-Series/Iarc-MonographsOn-The-Identification-Of-Carcinogenic-Hazards-To-Humans/HormonalContraception-And-Post-menopausal-Hormonal-Therapy-1999. Accessed January 2020

25. Bernstein L and Ross RK: Endogenous hormones and breast cancer risk. Epidemiol Rev 15: 48-65, 1993.

26. Henderson BE, Ross R and Bernstein L: Estrogens as a cause of human cancer: The richard and hinda rosenthal foundation award lecture. Cancer Res 48: 246-253, 1988.
27. NRC: Hormonally Active Agents in the Environmented. National Research Council, Washington (DC): The National Academies Press, 1999.

28. Greenman SB, Rutten MJ, Fowler WM, Scheffler L, Shortridge LA, Brown B, Sheppard BC, Deveney KE, Deveney CW and Trunkey DD: Herbicide/pesticide effects on intestinal epithelial growth. Environ Res 75: 85-93, 1997.

29. Valeron PF, Pestano JJ, Luzardo OP, Zumbado ML, Almeida M and Boada LD: Differential effects exerted on human mammary epithelial cells by environmentally relevant organochlorine pesticides either individually or in combination. Chem Biol Interact 180: 485-491, 2009.

30. Calaf GM and Garrido F: Catechol estrogens as biomarkers for mammary gland cancer. Int J Oncol 39: 177-183, 2011.

31. Calaf GM and Echiburu-Chau C: Synergistic effect of malathion and estrogen on mammary gland carcinogenesis. Oncol Rep 28: 640-646, 2012

32. Echiburu-Chau $\mathrm{C}$ and Calaf GM: Rat lung cancer induced by malathion and estrogen. Int J Oncol 33: 603-611, 2008.

33. Calaf GM and Roy D: Gene expression signature of parathion-transformed human breast epithelial cells. Int J Mol Med 19: 741-750, 2007.

34. Calaf GM and Roy D: Human drug metabolism genes in parathion-and estrogen-treated breast cells. Int J Mol Med 20: 875-881, 2007.

35. Calaf GM and Roy D: Cell adhesion proteins altered by 17 beta estradiol and parathion in breast epithelial cells. Oncol Rep 19: $165-169,2008$

36. Calaf GM, Echiburu-Chau C and Roy D: Organophosphorous pesticides and estrogen induce transformation of breast cells affecting p53 and c-Ha-ras genes. Int J Oncol 35: 1061-1068, 2009.

37. Calaf $G$ and Russo J: Transformation of human breast epithelial cells by chemical carcinogens. Carcinogenesis 14: 483-492, 1993

38. Calaf GM and Hei TK: Establishment of a radiation- and estrogen-induced breast cancer model. Carcinogenesis 21: 769-776, 2000

39. Gallardo M and Calaf GM: Curcumin and epithelial-mesenchymal transition in breast cancer cells transformed by low doses of radiation and estrogen. Int J Oncol 48: 2534-2542, 2016.

40. Calaf GM: Curcumin, oxidative stress and breast cancer, in Oxidative stress and dietary antioxidants, V. R. Preedy. Elsevier Inc., London, UK. pp159-169, 2014.

41. Calaf GM, Echiburu-Chau C, Roy D, Chai Y, Wen G and Balajee AS: Protective role of curcumin in oxidative stress of breast cells. Oncol Rep 26: 1029-1035, 2011

42. Guyton KZ, Rieswijk L, Wang A, Chiu WA and Smith MT: Key Characteristics Approach to Carcinogenic Hazard Identification. Chem Res Toxicol 31: 1290-1292, 2018.

43. Smith MT, Guyton KZ, Gibbons CF, Fritz JM, Portier CJ, Rusyn I, DeMarini DM, Caldwell JC, Kavlock RJ, Lambert PF, et al: Key Characteristics of carcinogens as a basis for organizing data on mechanisms of carcinogenesis. Environ Health Perspect 124: 713-721, 2016.

44. Cabello G, Valenzuela M, Vilaxa A, Duran V, Rudolph I, Hrepic N and Calaf G: A rat mammary tumor model induced by the organophosphorous pesticides parathion and malathion, possibly through acetylcholinesterase inhibition. Environ Health Perspect 109: 471-479, 2001.

45. Gwinn MR, Whipkey DL, Tennant LB and Weston A: Differential gene expression in normal human mammary epithelial cells treated with malathion monitored by DNA microarrays. Environ Health Perspect 113: 1046-10451, 2005.

46. Calaf GM, Alvarado ME and Hei TK: Beta catenin is associated with breast cancer progression in vitro. Int J Oncol 26: 913-921, 2005.

47. Calaf $\mathrm{G}$ and Hei TK: Oncoprotein expression in human breast epithelial cells transformed by high-LET radiation. Int J Radiat Biol 77: 31-40, 2001.

48. Nicolson GL: Cell membrane fluid-mosaic structure and cancer metastasis. Cancer Res 75: 1169-1176, 2015

49. Morrissey MA, Hagedorn EJ and Sherwood DR: Cell invasion through basement membrane: The netrin receptor DCC guides the way. Worm 2: e26169, 2013.

50. Naumann K: Synthetic Pyrethroid Insecticides: Structures and Properties. 1 edition. Chemistry of Plant Protection. Vol 4, Berlin, Germany, Springer-Verlag Berlin Heidelberg. XVI, 244, 1990.

51. Kim IY, Shin JH, Kim HS, Lee SJ, Kang IH, Kim TS, Moon HJ, Choi KS, Moon A and Han SY: Assessing estrogenic activity of pyrethroid insecticides using in vitro combination assays. J Reprod Dev 50: 245-255, 2004 
52. Isoda H, Talorete TP, Han J, Oka S, Abe Y and Inamori Y: Effects of organophosphorous pesticides used in china on various mammalian cells. Environ Sci 12: 9-19, 2005.

53. Calaf GM: Susceptibility of human breast epithelial cells in vitro to hormones and drugs. Int J Oncol 28: 285-295, 2006.

54. Fernandez PL, Jares P, Rey MJ, Campo E and Cardesa A: Cell cycle regulators and their abnormalities in breast cancer. Mol Pathol 51: 305-309, 1998.

55. Tenga MJ and Lazar IM: Proteomic snapshot of breast cancer cell cycle: G1/S transition point. Proteomics 13: 48-60, 2013.

56. Stopper H, Schmitt E, Gregor C, Mueller SO and Fischer WH: Increased cell proliferation is associated with genomic instability: Elevated micronuclei frequencies in estradiol-treated human ovarian cancer cells. Mutagenesis 18: 243-247, 2003.

57. Deshpande A, Sicinski P and Hinds PW: Cyclins and cdks in development and cancer: A perspective. Oncogene 24 2909-2915, 2005.

58. Hydbring P, Malumbres M and Sicinski P: Non-canonical functions of cell cycle cyclins and cyclin-dependent kinases. Nat Rev Mol Cell Biol 17: 280-292, 2016.

59. Petersen BO, Lukas J, Sorensen CS, Bartek J and Helin K: Phosphorylation of mammalian CDC6 by cyclin A/CDK2 regulates its subcellular localization. EMBO J 18: 396-410, 1999.

60. Saxena P: Comparative prediction of binding site of organophosphorus, carbamate and synthetic pyrethroid pesticides on human cyclin-dependent protein kinases Cdk2 and Cdk4. J Entomol Zoology Stud 2: 106-110, 2014.

61. Okuda T, Cleveland JL and Downing JR: PCTAIRE-1 and PCTAIRE-3, two members of a novel cdc2/CDC28-related protein kinase gene family. Oncogene 7: 2249-2258, 1992.

62. Serrano M, Hannon GJ and Beach D: A new regulatory motif in cell-cycle control causing specific inhibition of cyclin D/CDK4 Nature 366: 704-707, 1993.

63. Kato JY, Matsuoka M, Strom DK and Sherr CJ: Regulation of cyclin D-dependent kinase 4 (cdk4) by cdk4-activating kinase. Mol Cell Biol 14: 2713-2721, 1994.

64. MacLachlan TK, Sang N and Giordano A: Cyclins, cyclin-dependent kinases and cdk inhibitors: Implications in cell cycle control and cancer. Crit Rev Eukaryot Gene Expr 5: 127-156, 1995.

65. Tye BK: MCM proteins in DNA replication. Annu Rev Biochem 68: 649-486, 1999.

66. Labib K, Tercero JA and Diffley JF: Uninterrupted MCM2-7 function required for DNA replication fork progression Science 288: 1643-1647, 2000

67. Ryu S and Driever W: Minichromosome maintenance proteins as markers for proliferation zones during embryogenesis. Cell Cycle 5: 1140-1142, 2006.

68. Ren B, Cam H, Takahashi Y, Volkert T, Terragni J, Young RA and Dynlacht BD: E2F integrates cell cycle progression with DNA repair, replication, and $\mathrm{G}(2) / \mathrm{M}$ checkpoints. Genes Dev 16 : 245-256, 2002.

69. Pereverzeva I, Whitmire E, Khan B and Coue M: Distinct phosphoisoforms of the Xenopus $\mathrm{Mcm} 4$ protein regulate the function of the Mcm complex. Mol Cell Biol 20: 3667-3676, 2000.

70. Ishimi Y,Komamura-Kohno Y, You Z, Omori A and Kitagawa M Inhibition of Mcm 4,6,7 helicase activity by phosphorylation with cyclin A/Cdk2. J Biol Chem 275: 16235-16241, 2000.

71. Fujita M, Yamada C, Tsurumi T, Hanaoka F, Matsuzawa $\mathrm{K}$ and Inagaki M: Cell cycle- and chromatin binding state-dependent phosphorylation of human MCM heterohexameric complexes. A role for cdc2 kinase. J Biol Chem 273: 17095-17101, 1998.

72. Schories B, Engel K, Dorken B, Gossen M and Bommert K: Characterization of apoptosis-induced Mcm 3 and Cdc6 cleavage reveals a proapoptotic effect for one $\mathrm{Mcm} 3$ fragment. Cell Death Differ 11: 940-942, 2004

73. Koonin EV: A common set of conserved motifs in a vast variety of putative nucleic acid-dependent ATPases including MCM proteins involved in the initiation of eukaryotic DNA replication. Nucleic Acids Res 21: 2541-2547, 1993

74. Helfenstein A, Frahm SO, Krams M, Drescher W, Parwaresch R and Hassenpflug J: Minichromosome maintenance protein (MCM6) in low-grade chondrosarcoma: Distinction from enchondroma and identification of progressive tumors. Am J Clin Pathol 122: 912-918, 2004.

75. Duan X, Yang Y, Wang S, Feng X, Wang T, Wang P, Liu S, Li L, Yao W, Cui L and Wang W: Changes in the expression of genes involved in cell cycle regulation and the relative telomere length in the process of canceration induced by omethoate. Tumour Biol 39: 1010428317719782, 2017.
76. Qiu YL, Wang W, Wang T, Liu J, Sun P, Qian J, Jin L and Xia ZL: Genetic polymorphisms, messenger RNA expression of p53, p21, and CCND1, and possible links with chromosomal aberrations in Chinese vinyl chloride-exposed workers. Cancer Epidemio Biomarkers Prev 17: 2578-2584, 2008.

77. Lindstrom MS, Jin A, Deisenroth C, White Wolf G and Zhang Y: Cancer-associated mutations in the MDM2 zinc finger domain disrupt ribosomal protein interaction and attenuate MDM2-induced p53 degradation. Mol Cell Biol 27: 1056-1068, 2007.

78. Lee SS, Bohrson C, Pike AM, Wheelan SJ and Greider CW ATM kinase is required for telomere elongation in mouse and human cells. Cell Rep 13: 1623-1632, 2015.

79. Yang-Snyder J, Miller JR, Brown JD, Lai CJ and Moon RT: A frizzled homolog functions in a vertebrate Wnt signaling pathway. Curr Biol 6: 1302-1306, 1996.

80. Sharma M, Castro-Piedras I, Simmons GE Jr and Pruitt K: Dishevelled: A masterful conductor of complex Wnt signals. Cell Signal 47: 52-64, 2018.

81. Masckauchan TN, Agalliu D, Vorontchikhina M, Ahn A, Parmalee NL, Li CM, Khoo A, Tycko B, Brown AM and Kitajewski J: Wnt5a signaling induces proliferation and survival of endothelial cells in vitro and expression of MMP-1 and Tie-2. Mol Biol Cell 17: 5163-5172, 2006.

82. Sussman DJ, Klingensmith J, Salinas P, Adams PS, Nusse R and Perrimon N: Isolation and characterization of a mouse homolog of the Drosophila segment polarity gene dishevelled. Dev Biol 166: 73-86, 1994

83. Testa JR, Zhou JY, Bell DW and Yen TJ: Chromosomal localization of the genes encoding the kinetochore proteins CENPE and CENPF to human chromosomes $4 \mathrm{q} 24-->\mathrm{q} 25$ and $1 \mathrm{q} 32-->\mathrm{q} 41$, respectively, by fluorescence in situ hybridization. Genomics 23 : 691-693, 1994.

84. Trinh BN, Ong CN, Coetzee GA, Yu MC and Laird PW: Thymidylate synthase: A novel genetic determinant of plasma homocysteine and folate levels. Hum Genet 111: 299-302, 2002.

85. Chang H, Qi X, Trieu Y, Xu W, Reader JC, Ning Y and Reece D: Multiple myeloma patients with CKS1B gene amplification have a shorter progression-free survival post-autologous stem cell transplantation. Br J Haematol 135: 486-491, 2006.

86. Russo J, Tahin Q, Lareef MH, Hu YF and Russo IH: Neoplastic transformation of human breast epithelial cells by estrogens and chemical carcinogens. Environ Mol Mutagen 39: 254-263, 2002.

87. Reynolds FH Jr, Todaro GJ, Fryling C and Stephenson JR: Human transforming growth factors induce tyrosine phosphorylation of EGF receptors. Nature 292: 259-262, 1981.

88. Hines SJ, Litz JS and Krystal GW: Coexpression of c-kit and stem cell factor in breast cancer results in enhanced sensitivity to members of the EGF family of growth factors. Breast Cancer Res Treat 58: 1-10, 1999.

89. Wee $\mathrm{P}$ and Wang Z: Epidermal growth factor receptor cell proliferation signaling pathways. Cancers (Basel) 9: 52, 2017.

90. Wang Z: ErbB receptors and cancer. Methods Mol Biol 1652: 3-35, 2017.

91. Nicholson RI, Gee JM and Harper ME: EGFR and cancer prognosis. Eur J Cancer 37 (Suppl 4): S9-S15, 2001.

92. Lippman M, Bolan G and Huff K: The effects of estrogens and antiestrogens on hormone-responsive human breast cancer in long-term tissue culture. Cancer Res 36: 4595-4601, 1976.

93. Dickson RB and Lippman ME: Control of human breast cancer by estrogen, growth factors, and oncogenes. Cancer Treat Res 40: $119-165,1988$.

94. Yamamoto KR: Steroid receptor regulated transcription of specific genes and gene networks. Annu Rev Genet 19: 209-252, 1985.

95. Marino M, Galluzzo P and Ascenzi P: Estrogen signaling multiple pathways to impact gene transcription. Curr Genomics 7: 497-508, 2006.

96. Pratt WB and Toft DO: Steroid receptor interactions with heat shock protein and immunophilin chaperones. Endocr Rev 18: 306-360, 1997.

97. Yasar P, Ayaz G, User SD, Gupur G and Muyan M: Molecular mechanism of estrogen-estrogen receptor signaling. Reprod Med Biol 16: 4-20, 2017.

98. Safe S: Transcriptional activation of genes by 17 beta-estradiol through estrogen receptor-Sp1 interactions. Vitam Horm 62: 231-252, 2001.

99. Bjornstrom L and Sjoberg M: Mutations in the estrogen receptor DNA-binding domain discriminate between the classical mechanism of action and cross-talk with Stat $5 \mathrm{~b}$ and activating protein 1 (AP-1). J Biol Chem 277: 48479-48483, 2002. 
100. Garcia-Becerra R, Santos N,Diaz L and Camacho J: Mechanisms of resistance to endocrine therapy in breast cancer: Focus on signaling pathways, miRNAs and genetically based resistance. Int J Mol Sci 14: 108-145, 2012.

101. Felipe Lima J, Nofech-Mozes S, Bayani J and Bartlett JM: EMT in breast carcinoma-a review. J Clin Med 5: 65, 2016.

102. Calaf GM, Bleak TC, Munoz JP and Aguayo F: Markers of epithelial-mesenchymal transition in an experimental breast cancer model induced by organophosphorous pesticides and estrogen. Oncol Lett 20: 84, 2020.

103. Conney AH, Welch RM, Kuntzman R and Burns JJ: Effects of pesticides on drug and steroid metabolism. Clin Pharmacol Ther 8: 2-10, 1967.

104. Taxak N and Bharatam PV: Drug metabolism: A fascinating link between chemistry and biology. Resonance 19: 259-282, 2014.

105. Di L and Kerns EH: Metabolic Stability, in Drug-Like Properties: Concepts, Structure Design and Methods from ADME to Toxicity Optimization, E. H. K. Li Di. Elsevier. pp161-194, 2016

106. Chen TL, Lin CJ and Liu CC: Cytochrome P450-dependent monooxygenase system and anesthetics. Acta Anaesthesiol Sin 33: 185-194, 1995 (In Chinese).

107. Bernstein L, Ross RK, Pike MC, Brown JB and Henderson BE: Hormone levels in older women: A study of post-menopausal breast cancer patients and healthy population controls. $\mathrm{Br}$ J Cancer 61: 298-302, 1990.

108. Dubey RK and Jackson EK: Estrogen-induced cardiorenal protection: Potential cellular, biochemical, and molecular mechanisms. Am J Physiol Renal Physiol 280: F365-F388, 2001

109. Yue W, Santen RJ, Wang JP, Li Y, Verderame MF, Bocchinfuso WP, Korach KS, Devanesan P, Todorovic R, Rogan EG and Cavalieri EL: Genotoxic metabolites of estradiol in breast: Potential mechanism of estradiol induced carcinogenesis. J Steroid Biochem Mol Biol 86: 477-486, 2003.

110. Williamson LM and Lees-Miller SP: Estrogen receptor alpha-mediated transcription induces cell cycle-dependent DNA double-strand breaks. Carcinogenesis 32: 279-285, 2011.

111. Yang KJ, Lee J and Park HL: Organophosphate pesticide exposure and breast cancer risk: A rapid review of human, animal, and cell-based studies. Int J Environ Res Public Health 17: 5030, 2020.

112. Telang NT, Suto A, Wong GY, Osborne MP and Bradlow HL: Induction by estrogen metabolite 16 alpha-hydroxyestrone of genotoxic damage and aberrant proliferation in mouse mammary epithelial cells. J Natl Cancer Inst 84: 634-638, 1992

113. Bay BH, Jin R, Huang J and Tan PH: Metallothionein as a prognostic biomarker in breast cancer. Exp Biol Med (Maywood) 231 $1516-1521,2006$.

114. Si M and Lang J: The roles of metallothioneins in carcinogenesis. J Hematol Oncol 11: 107, 2018.

115. Lai Y, Yip GW and Bay BH: Targeting metallothionein for prognosis and treatment of breast cancer. Recent Pat Anticancer Drug Discov 6: 178-185, 2011.

116. Jin R, Chow VT, Tan PH, Dheen ST, Duan W and Bay BH: Metallothionein 2A expression is associated with cell proliferation in breast cancer. Carcinogenesis 23: 81-86, 2002.

117. Nascimento H, Coy CS, Teori MT, Boin IF, Goes JR, Costa FF and Lima CS: Possible influence of glutathione S-transferase GSTT1 null genotype on age of onset of sporadic colorectal adenocarcinoma. Dis Colon Rectum 46: 510-515, 2003

118. Rebbeck TR: Molecular epidemiology of the human glutathione S-transferase genotypes GSTM1 and GSTT1 in cancer susceptibility. Cancer Epidemiol Biomarkers Prev 6: 733-743, 1997.

119. Dalhoff K, Buus Jensen K and Enghusen Poulsen H: Cancer and molecular biomarkers of phase 2. Methods Enzymol 400: 618-627, 2005.

120. Slattery ML, Curtin K, Ma K, Schaffer D, Potter J and Samowitz W: GSTM-1 and NAT2 and genetic alterations in colon tumors. Cancer Causes Control 13: 527-534, 2002.

121. Liu X, Li Z, Zhang Z, Zhang W, Li W, Xiao Z, Liu H, Jiao H, Wang Y and Li G: Meta-analysis of GSTM1 null genotype and lung cancer risk in Asians. Med Sci Monit 20: 1239-1245, 2014

122. Yu C, Hequn C, Longfei L, Long W, Zhi C, Feng Z, Jinbo C, Chao L and Xiongbing Z: GSTM1 and GSTT1 polymorphisms are associated with increased bladder cancer risk: Evidence from updated meta-analysis. Oncotarget 8: 3246-3258, 2017.

123. Martignano F, Gurioli G, Salvi S, Calistri D, Costantini M, Gunelli R, De Giorgi U, Foca F and Casadio V: GSTP1 methylation and protein expression in prostate cancer: Diagnostic implications. Dis Markers 2016: 4358292, 2016.
124. Gamage N, Barnett A, Hempel N, Duggleby RG, Windmill KF, Martin JL and McManus ME: Human sulfotransferases and their role in chemical metabolism. Toxicol Sci 90: 5-22, 2006.

125. Paul P, Suwan J, Liu J, Dordick JS and Linhardt RJ: Recent advances in sulfotransferase enzyme activity assays. Anal Bioanal Chem 403: 1491-1500, 2012.

126. Hajishengallis GN and Apostolopoulos AX: Glucosyltransferase (GTF) and immunization against dental caries in humans. Odontostomatol Proodos 43: 315-321, 1989 (In Modern Greek).

127. Breton C, Snajdrova L, Jeanneau C, Koca J and Imberty A Structures and mechanisms of glycosyltransferases. Glycobiology 16: 29R-37R, 2006.

128. Maiti S and Nazmeen A: Impaired redox regulation of estrogen metabolizing proteins is important determinant of human breast cancers. Cancer Cell Int 19: 111, 2019.

129. Subbarayan K and Seliger B: Tumor-dependent effects of proteoglycans and various glycosaminoglycan synthesizing enzymes and sulfotransferases on patients' outcome. Curr Cancer Drug Targets 19: 210-221, 2019.

130. Collier AC, Yamauchi Y, Sato BL, Rougee LR and Ward MA: UDP-glucuronosyltransferase la enzymes are present and active in the mouse blastocyst. Drug Metab Dispos 42: 1921-1925, 2014.

131. Kirkman H: Estrogen-induced tumors of the kidney. III. Growth characteristics in the Syrian hamster. Natl Cancer Inst Monogr 1: 1-57, 1959.

132. Li JJ, Li SA, Klicka JK, Parsons JA and Lam LK: Relative carcinogenic activity of various synthetic and natural estrogens in the Syrian hamster kidney. Cancer Res 43: 5200-5204, 1983.

133. Liehr JG, Fang WF, Sirbasku DA and Ari-Ulubelen A Carcinogenicity of catechol estrogens in syrian hamsters. J Steroid Biochem 24: 353-356, 1986.

134. Liehr JG and Ricci MJ: 4-Hydroxylation of estrogens as marker of human mammary tumors. Proc Natl Acad Sci USA 93: 3294-3296, 1996.

135. Zhu BT and Conney AH: Functional role of estrogen metabolism in target cells: Review and perspectives. Carcinogenesis 19: 1-27, 1998.

136. Palackal NT, Lee SH, Harvey RG, Blair IA and Penning TM: Activation of polycyclic aromatic hydrocarbon trans-dihydrodiol proximate carcinogens by human aldo-keto reductase (AKR1C) enzymes and their functional overexpression in human lung carcinoma (A549) cells. J Biol Chem 277: 24799-24808, 2002.

137. Satoh T and Gupta RC (eds): Anticholinesterase Pesticides: Metabolism, Neurotoxicity, and Epidemiologyed. John Wiley \& Sons, pp644, 2011.

138. Barski OA, Tipparaju SM and Bhatnagar A: The aldo-keto reductase superfamily and its role in drug metabolism and detoxification. Drug Metab Rev 40: 553-624, 2008.

139. Raif A, Marshall GM, Bell JL, Koach J, Tan O, D'Andreti C, Thomas W, Sekyere E, Norris M, Haber M, et al: The estrogen-responsive B box protein (EBBP) restores retinoid sensitivity in retinoid-resistant cancer cells via effects on histone acetylation. Cancer Lett 277: 82-90, 2009.

140. Lasram MM, Bouzid K, Douib IB, Annabi A, El Elj N, El Fazaa S, Abdelmoula J and Gharbi N: Lipid metabolism disturbances contribute to insulin resistance and decrease insulin sensitivity by malathion exposure in Wistar rat. Drug Chem Toxicol 38: 227-234, 2015.

141. Rahimi R and Abdollahi M: A review on the mechanisms involved in hyperglycemia induced by organophosphorus pesticides. Pest Biochem Physiol 88: 115-121, 2007.

142. Lasram MM, Annabi AB, El Elj N, Selmi S, Kamoun A, El-Fazaa S and Gharbi N: Metabolic disorders of acute exposure to malathion in adult Wistar rats. J Hazard Mater 163: 1052-1055, 2009.

143. Lasram MM, Annabi AB, Rezg R, Elj N, Selmi S, Kamoun A, El-Fazaa $S$ and Gharbi N: Effect of short-time malathion administration on glucose homeostasis in Wistar rat. Pestic Biochem Phys 92: 114-119, 2008

144. Panahi P, Vosough-Ghanbari S, Pournourmohammadi S, Ostad SN, Nikfar S, Minaie B and Abdollahi M: Stimulatory effects of malathion on the key enzymes activities of insulin secretion in langerhans islets, glutamate dehydrogenase and glucokinase. Toxicol Mech Methods 16: 161-167, 2006

145. Abdollahi M, Donyavi M, Pournourmohammadi S and Saadat M: Hyperglycemia associated with increased hepatic glycogen phosphorylase and phosphoenolpyruvate carboxykinase in rats following subchronic exposure to malathion. Comp Biochem Physiol C Toxicol Pharmacol 137: 343-347, 2004 
146. Kalender S, Uzun FG, Durak D, Demir F and Kalender Y: Malathion-induced hepatotoxicity in rats: The effects of vitamins $C$ and E. Food Chem Toxicol 48: 633-638, 2010.

147. Rezg R, Mornagui B, Benahmed M, Chouchane SG, Belhajhmida N, Abdeladhim M, Kamoun A, El-fazaa S and Gharbi N: Malathion exposure modulates hypothalamic gene expression and induces dyslipedemia in Wistar rats. Food Chem Toxicol 48: 1473-1477, 2010.

148. Lassiter TL, Ryde IT, Levin ED, Seidler FJ and Slotkin TA: Neonatal exposure to parathion alters lipid metabolism in adulthood: Interactions with dietary fat intake and implications for neurodevelopmental deficits. Brain Res Bull 81: 85-91, 2010.

149. Fang $\mathrm{H}$ and Judd RL: Adiponectin regulation and function. Compr Physiol 8: 1031-1063, 2018.

150. Josephs SF, Ichim TE, Prince SM, Kesari S, Marincola FM, Escobedo AR and Jafri A: Unleashing endogenous TNF-alpha as a cancer immunotherapeutic. J Transl Med 16: 242, 2018.

151. Wajant H: The role of TNF in cancer. Results Probl Cell Differ 49: 1-15, 2009

152. Wang $\mathrm{H}$ and Wang WJ: Relationship between CYP1A1 polymorphisms and invasion and metastasis of breast cancer. Asian Pac J Trop Med 6: 835-838, 2013.

153. Broustas CG and Lieberman HB: DNA damage response genes and the development of cancer metastasis. Radiat Res 181: 111-130, 2014

154. Elenbaas B, Spirio L, Koerner F, Fleming MD, Zimonjic DB, Donaher JL, Popescu NC, Hahn WC and Weinberg RA: Human breast cancer cells generated by oncogenic transformation of primary mammary epithelial cells. Genes Dev 15: 50-65, 2001.

155. Schubbert S, Shannon K and Bollag G: Hyperactive Ras in developmental disorders and cancer. Nat Rev Cancer 7: 295-308, 2007.

156. Roy D, Calaf G and Hei TK: Allelic imbalance at 11p15.5-15.4 correlated with c-Ha-ras mutation during radiation-induced neoplastic transformation of human breast epithelial cells. Int J Cancer 103: 730-737, 2003.

157. Roy D, Calaf G and Hei TK: Frequent allelic imbalance on chromosome 6 and 17 correlate with radiation-induced neoplastic transformation of human breast epithelial cells. Carcinogenesis 22: 1685-1692, 2001

158. Zhang PL, Calaf G and Russo J: Allele loss and point mutation in codons 12 and 61 of the c-Ha-ras oncogene in carcinogen-transformed human breast epithelial cells. Mol Carcinog 9: 46-56, 1994

159. Lin JC, Wang CC, Jiang RS, Wang WY and Liu SA: Microsatellite alteration in head and neck squamous cell carcinoma patients from a betel quid-prevalent region. Sci Rep 6: 22614, 2016

160. Hadziavdic V, Pavlovic-Calic N and Eminovic I: Microsatellite instability and loss of heterozygosity of tumor suppressor genes in Bosnian patients with sporadic colorectal cancer. Bosn J Basic Med Sci 8: 313-321, 2008

161. Chambuso R, Kaambo E, Denny L, Gray CM, Williamson AL, Migdalska-Sek M, Agenbag G, Rebello G and Ramesar R: Investigation of cervical tumor biopsies for chromosomal loss of heterozygosity ( $\mathrm{LOH}$ ) and microsatellite instability (MSI) at the HLA II locus in HIV-1/HPV Co-infected Women. Front Oncol 9: 951, 2019.

162. Boland CR and Goel A: Microsatellite instability in colorectal cancer. Gastroenterology 138: 2073-2087.e3, 2010.

163. Kim TM and Park PJ: A genome-wide view of microsatellite instability: Old stories of cancer mutations revisited with new sequencing technologies. Cancer Res 74: 6377-6382, 2014

164. Banys-Paluchowski M, Fehm T, Janni W, Aktas B, Fasching PA, Kasimir-Bauer S, Milde-Langosch K, Pantel K, Rack B, Riethdorf S, et al: Elevated serum RAS p21 is an independent prognostic factor in metastatic breast cancer. BMC Cancer 18 $541,2018$.

165. Spandidos DA, Karaiossifidi H, Malliri A, Linardopoulos S, Vassilaros S, Tsikkinis A and Field JK: Expression of ras Rb1 and p53 proteins in human breast cancer. Anticancer Res 12 $81-89,1992$

166. Calaf GM and Abarca-Quinones J: Ras protein expression as a marker for breast cancer. Oncol Lett 11: 3637-3642, 2016.

167. Didsbury J, Weber RF, Bokoch GM, Evans T and Snyderman R: Rac, a novel ras-related family of proteins that are botulinum toxin substrates. J Biol Chem 264: 16378-16382, 1989.

168. Wennerberg K, Rossman KL and Der CJ: The Ras superfamily at a glance. J Cell Sci 118: 843-846, 2005.

169. Fritz G, Brachetti C, Bahlmann F, Schmidt M and Kaina B: Rho GTPases in human breast tumours: Expression and mutation analyses and correlation with clinical parameters. $\mathrm{Br}$ J Cancer 87: 635-644, 2002
170. Kleer CG, van Golen KL, Zhang Y, Wu ZF, Rubin MA and Merajver SD: Characterization of RhoC expression in benign and malignant breast disease: A potential new marker for small breast carcinomas with metastatic ability. Am J Pathol 160: 579-584, 2002.

171. Bustelo XR, Sauzeau V and Berenjeno IM: GTP-binding proteins of the Rho/Rac family: Regulation, effectors and functions in vivo. Bioessays 29: 356-370, 2007.

172. Skowronek KR, Guo F, Zheng Y and Nassar N: The C-terminal basic tail of RhoG assists the guanine nucleotide exchange factor trio in binding to phospholipids. J Biol Chem 279: 37895-37907, 2004.

173. Ko CD, Kim JS, Ko BG, Son BH, Kang HJ, Yoon HS, Cho EY, Gong $\mathrm{G}$ and Ahn SH: The meaning of the c-kit proto-oncogene product in malignant transformation in human mammary epithelium. Clin Exp Metastasis 20: 593-597, 2003.

174. Najafi M, Ahmadi A and Mortezaee K: Extracellular-signal-regulated kinase/mitogen-activated protein kinase signaling as a target for cancer therapy: An updated review. Cell Biol Int 43: 1206-1222, 2019.

175. Turner N and Grose R: Fibroblast growth factor signalling: From development to cancer. Nat Rev Cancer 10: 116-129, 2010.

176. Carter EP, Fearon AE and Grose RP: Careless talk costs lives: Fibroblast growth factor receptor signalling and the consequences of pathway malfunction. Trends Cell Biol 25: 221-233, 2015.

177. Ak1 MR, Nagpal P, Ayoub NM, Tai B, Prabhu SA, Capac CM, Gliksman M, Goy A and Suh KS: Molecular and clinical significance of fibroblast growth factor 2 (FGF2/bFGF) in malignancies of solid and hematological cancers for personalized therapies. Oncotarget 7: 44735-44762, 2016.

178. Wesche J, Haglund K and Haugsten EM: Fibroblast growth factors and their receptors in cancer. Biochem J 437: 199-213, 2011.

179. Zakrzewska M, Marcinkowska E and Wiedlocha A: FGF-1: From biology through engineering to potential medical applications. Crit Rev Clin Lab Sci 45: 91-135, 2008.

180. Hu Z, Evarts RP, Fujio K, Omori N, Omori M, Marsden ER and Thorgeirsson SS: Expression of transforming growth factor alpha/epidermal growth factor receptor, hepatocyte growth factor/c-met and acidic fibroblast growth factor/fibroblast growth factor receptors during hepatocarcinogenesis. Carcinogenesis 17: 931-938, 1996.

181. Chow NH, Cheng KS, Lin PW, Chan SH, Su WC, Sun YN and Lin XZ: Expression of fibroblast growth factor-1 and fibroblast growth factor-2 in normal liver and hepatocellular carcinoma. Dig Dis Sci 43: 2261-2266, 1998.

182. Yamanaka Y, Friess H, Buchler M, Beger HG, Uchida E, Onda M, Kobrin MS and Korc M: Overexpression of acidic and basic fibroblast growth factors in human pancreatic cancer correlates with advanced tumor stage. Cancer Res 53: 5289-5296, 1993

183. Soufla G, Sifakis S and Spandidos DA: FGF2 transcript levels are positively correlated with EGF and IGF-1 in the malignant endometrium. Cancer Lett 259: 146-155, 2008.

184. Watnick RS: The role of the tumor microenvironment in regulating angiogenesis. Cold Spring Harb Perspect Med 2: a006676, 2012.

185. Schmid C: Insulin-like growth factors. Cell Biol Int 19: 445-457, 1995.

186. Baxter RC: Insulin-like growth factor binding proteins as glucoregulators. Metabolism 44 (10 Suppl 4): S12-S17, 1995.

187. Kelley KM, Oh Y, Gargosky SE, Gucev Z, Matsumoto T, Hwa V, Ng L, Simpson DM and Rosenfeld RG: Insulin-like growth factor-binding proteins (IGFBPs) and their regulatory dynamics. Int J Biochem Cell Biol 28: 619-637, 1996.

188. Oh Y, Nagalla SR, Yamanaka Y, Kim HS, Wilson E and Rosenfeld RG: Synthesis and characterization of insulin-like growth factor-binding protein (IGFBP)-7. Recombinant human mac25 protein specifically binds IGF-I and -II. J Biol Chem 271: 30322-30325, 1996

189. Mnif W, Hassine AI, Bouaziz A, Bartegi A, Thomas O and Roig B: Effect of endocrine disruptor pesticides: A review. Int J Environ Res Public Health 8: 2265-2303, 2011.

190. Takayama T, Shiozaki H, Shibamoto S, Oka H, Kimura Y, Tamura S, Inoue M, Monden T, Ito F and Monden M: Beta-catenin expression in human cancers. Am J Pathol 148: 39-46, 1996.

191. Breen E, Steele G Jr and Mercurio AM: Role of the E-cadherin/alpha-catenin complex in modulating cell-cell and cell-matrix adhesive properties of invasive colon carcinoma cells. Ann Surg Oncol 2: 378-385, 1995.

192. Lim SC and Lee MS: Significance of E-cadherin/beta-catenin complex and cyclin D1 in breast cancer. Oncol Rep 9: 915-928, 2002 . 
193. Nakopoulou L, Gakiopoulou-Givalou H, Karayiannakis AJ, Giannopoulou I, Keramopoulos A, Davaris P and Pignatelli M Abnormal alpha-catenin expression in invasive breast cancer correlates with poor patient survival. Histopathology 40: 536-546, 2002

194. Pierceall WE, Woodard AS, Morrow JS, Rimm D and Fearon ER: Frequent alterations in E-cadherin and alpha- and beta-catenin expression in human breast cancer cell lines. Oncogene 11: 1319-1326, 1995.

195. Lewis JA, Szilagyi M, Gehman E, Dennis WE and Jackson DA: Distinct patterns of gene and protein expression elicited by organophosphorus pesticides in Caenorhabditis elegans. BMC Genomics 10: 202, 2009.

196. Williams PL and Dusenbery DB: Using the nematode Caenorhabditis elegans to predict mammalian acute lethality to metallic salts. Toxicol Ind Health 4: 469-478, 1988.

197. Morgan PG and Sedensky MM: Mutations affecting sensitivity to ethanol in the nematode, Caenorhabditis elegans. Alcohol Clin Exp Res 19: 1423-1429, 1995.

198. Bargmann CI: Neurobiology of the Caenorhabditis elegans genome. Science 282: 2028-2033, 1998.

199. Cole RD, Anderson GL and Williams PL: The nematode Caenorhabditis elegans as a model of organophosphate-induced mammalian neurotoxicity. Toxicol Appl Pharmacol 194: 248-256, 2004

200. Jin HJ, Kwon JH, Kim M, Bae YK, Choi SJ, Oh W, Yang YS and Jeon HB: Downregulation of melanoma cell adhesion molecule (MCAM/CD146) accelerates cellular senescence in human umbilical cord blood-derived mesenchymal stem cells. Stem Cells Transl Med 5: 427-439, 2016.

201. Leroyer AS, Blin MG, Bachelier R, Bardin N, Blot-Chabaud M and Dignat-George F: CD146 (Cluster of Differentiation 146). Arterioscler Thromb Vasc Biol 39: 1026-1033, 2019.

202. Ye Z, Zhang C, Tu T, Sun M, Liu D, Lu D, Feng J, Yang D, Liu F and Yan X: Wnt5a uses CD146 as a receptor to regulate cell motility and convergent extension. Nat Commun 4: 2803, 2013

203. Kang Y, Wang F, Feng J, Yang D, Yang X and Yan X: Knockdown of CD146 reduces the migration and proliferation of human endothelial cells. Cell Res 16: 313-318, 2006.

204. Ouhtit A, Gaur RL, Abd Elmageed ZY, Fernando A, Thouta R, Trappey AK, Abdraboh ME, El-Sayyad HI, Rao P and Raj MG: Towards understanding the mode of action of the multifaceted cell adhesion receptor CD146. Biochim Biophys Acta 1795 130-136, 2009.

205. Coulombe PA and Omary MB: 'Hard' and 'soft' principles defining the structure, function and regulation of keratin intermediate filaments. Curr Opin Cell Biol 14: 110-122, 2002.

206. Greystoke A, Dean E, Saunders MP, Cummings J, Hughes A Ranson M, Dive C and Renehan AG: Multi-level evidence that circulating CK18 is a biomarker of tumour burden in colorectal cancer. Br J Cancer 107: 1518-1524, 2012.

207. Schneider J: Tumor markers in detection of lung cancer. Adv Clin Chem 42: 1-41, 2006

208. Moll R, Divo M and Langbein L: The human keratins: Biology and pathology. Histochem Cell Biol 129: 705-733, 2008.

209. Ahn SK, Moon HG, Ko E, Kim HS, Shin HC, Kim J, You JM, Han W and Noh DY: Preoperative serum tissue polypeptide-specific antigen is a valuable prognostic marker in breast cancer. Int J Cancer 132: 875-881, 2013.

210. Escobar-Hoyos LF, Shah R, Roa-Pena L, Vanner EA, Najafian N Banach A, Nielsen E, Al-Khalil R, Akalin A, Talmage D, et al: Keratin-17 promotes p27KIP1 nuclear export and degradation and offers potential prognostic utility. Cancer Res 75 3650-3662, 2015.

211. Tan HS, Jiang WH, He Y, Wang DS, Wu ZJ, Wu DS, Gao L, Bao Y, Shi JZ, Liu B, et al: KRT8 upregulation promotes tumor metastasis and is predictive of a poor prognosis in clear cell renal cell carcinoma. Oncotarget 8: 76189-76203, 2017.

212. Cheung KJ, Padmanaban V, Silvestri V, Schipper K, Cohen JD, Fairchild AN, Gorin MA, Verdone JE, Pienta KJ, Bader JS and Ewald AJ: Polyclonal breast cancer metastases arise from collective dissemination of keratin 14-expressing tumor cell clusters. Proc Natl Acad Sci USA 113: E854-E863, 2016.

213. Saha SK, Choi HY, Kim BW, Dayem AA, Yang GM, Kim KS, Yin YF and Cho SG: KRT19 directly interacts with beta-catenin/RAC1 complex to regulate NUMB-dependent NOTCH signaling pathway and breast cancer properties. Oncogene 36: 332-349, 2017.

214. Zhang B, Wang J, Liu W, Yin Y, Qian D, Zhang H, Shi B, Li C Zhu J, Zhang L, et al: Cytokeratin 18 knockdown decreases cell migration and increases chemosensitivity in non-small cell lung cancer. J Cancer Res Clin Oncol 142: 2479-2487, 2016.
215. Yin B, Zhang M, Zeng Y, Li Y, Zhang C, Getzenberg RH and Song Y: Downregulation of cytokeratin 18 is associated with paclitaxelresistance and tumor aggressiveness in prostate cancer. Int J Oncol 48: 1730-1736, 2016.

216. Miller DJ and Fort PE: Heat shock proteins regulatory role in neurodevelopment. Front Neurosci 12: 821, 2018.

217. Schlesinger MJ, Ashburner M and Tissières A (eds): Heat Shock: From bacteria to man. Cold Spring Harbor Laboratory, Cold Spring Harbor, NY, 1982.

218. Zeilstra-Ryalls J, Fayet $\mathrm{O}$ and Georgopoulos C: The universally conserved GroE (Hsp60) chaperonins. Annu Rev Microbiol 45: 301-325, 1991.

219. Georgopoulos C and Welch WJ: Role of the major heat shock proteins as molecular chaperones. Annu Rev Cell Biol 9: 601-634, 1993.

220. Ohtsuka K: Cloning of a cDNA for heat-shock protein hsp40, a human homologue of bacterial DnaJ. Biochem Biophys Res Commun 197: 235-240, 1993.

221. Todd MJ, Viitanen PV and Lorimer GH: Dynamics of the chaperonin ATPase cycle: Implications for facilitated protein folding. Science 265: 659-566, 1994.

222. Meher PK, Sahu TK, Gahoi S and Rao AR: ir-HSP: Improved recognition of heat shock proteins, their families and sub-types based On g-Spaced Di-peptide features and support vector machine. Front Genet 8: 235, 2017.

223. Lee CH, Hong HM, Chang YY and Chang WW: Inhibition of heat shock protein (Hsp) 27 potentiates the suppressive effect of Hsp90 inhibitors in targeting breast cancer stem-like cells. Biochimie 94: 1382-1389, 2012.

224. Werner I, Koger CS, Hamm JT and Hinton DE: Ontogeny of the heat shock protein, hsp70 and hsp60, response and developmental effects of heat-shock in the teleost, medaka (Oryzias latipes). Environmental Sci 8: 13-29, 2001.

225. Levine AJ, Momand $\mathrm{J}$ and Finlay CA: The p53 tumour suppressor gene. Nature 351: 453-456, 1991.

226. Callahan R: p53 mutations, another breast cancer prognostic factor. J Natl Cancer Inst 84: 826-827, 1992

227. Moll UM, Ostermeyer AG, Ahomadegbe JC, Mathieu MC and Riou G: p53 mediated tumor cell response to chemotherapeutic DNA damage: A preliminary study in matched pairs of breast cancer biopsies. Hum Pathol 26: 1293-1301, 1995.

228. Nigro JM, Baker SJ, Preisinger AC, Jessup JM, Hostetter R, Cleary K, Bigner SH, Davidson N, Baylin S, Devilee P, et al: Mutations in the p53 gene occur in diverse human tumour types. Nature 342: 705-708, 1989

229. Migdalska-Sek M,Pastuszak-Lewandoska D and Brzezianska E: MSI and LOH in the development and prognosis of follicular cell-derived thyroid tumours. Endokrynol Pol 63: 126-136, 2012.

230. Kiaris $\mathrm{H}$ and Spandidos D: Mutations of ras genes in human tumors (review). Int J Oncol 7: 413-421, 1995.

231. Samowitz WS, Holden JA, Curtin K, Edwards SL, Walker AR, Lin HA, Robertson MA, Nichols MF, Gruenthal KM, Lynch BJ, et al: Inverse relationship between microsatellite instability and K-ras and p53 gene alterations in colon cancer. Am J Pathol 158: 1517-1524, 2001

232. Mendez O, Manas S, Peinado, Fabra A, Escobedo A, Moreno A and Sierra A: Microsatellite instability is associated with the loss of apoptosis in ductal breast carcinomas. Breast Cancer Res Treat 65: 171-177, 2001

233. Appella E and Anderson CW: Post-translational modifications and activation of p53 by genotoxic stresses. Eur J Biochem 268: 2764-2772, 2001.

234. Lee E, Oh E, Lee J, Sul D and Lee J: Use of the tail moment of the lymphocytes to evaluate DNA damage in human biomonitoring studies. Toxicol Sci 81: 121-132, 2004

235. Kumar N, Yadav A, Gulati S, Priya K, Aggarwal N and Gupta R: Effects of GST polymorphism on ameliorative effect of curcumin and carvacrol against DNA damage induced by combined treatment of malathion and parathion. IJT 10: 19-27, 2016.

236. Collins AR: The comet assay for DNA damage and repair: Principles, applications, and limitations. Mol Biotechnol 26 249-261, 2004.

237. Moore PD, Yedjou CG and Tchounwou PB: Malathion-induced oxidative stress, cytotoxicity, and genotoxicity in human liver carcinoma (HepG2) cells. Environ Toxicol 25: 221-226, 2010. International (CC BY-NC-ND 4.0) License. 